MICHAEL L. WACHTER

University of Pennsylvania

WILLIAM H. CARTER

University of Pennsylvania

\title{
Norm Shifts in Union Wages: Will 1989 Be a Replay of 1969?
}

THE U.S. economic expansion of the 1980s is frequently compared with that of the 1960s, with the similarities extending to inflation and the labor market. For example, during both the 1980s and the 1960s inflation was lower than predicted, and during both decades low rates of wage increases contributed to the surprisingly low inflation rates. After 1969, however, the core rate of inflation trended higher, with wage gains leading the way, even in the midst of the impending recession. ${ }^{1}$

Unions have long been considered inflation's wild card. They helped lower inflation during the 1960 s and 1980s, but played the opposite role during the stagflation of the 1970s. ${ }^{2}$ The question that we address in this paper is whether unions are more likely to be a positive or negative wild card over the next few years.

After a brief review of the data on recent wage increases, we narrow

Research support was provided by the Institute for Law and Economics, University of Pennsylvania. We wish to thank Robert J. Gordon for his assistance on the union and nonunion sector wage equations and members of the Brookings Panel for many helpful suggestions. Special thanks also go to Harriet Weinstein and Alvin Bauman of the Bureau of Labor Statistics for help with the collective bargaining data, Martha Keon for editing assistance, and Richard Ferris for comments on an earlier draft.

1. It was the shift in wage behavior in 1970 that led George Perry to argue that wage norms and largely nonlinear shifts in those norms played a significant role in the inflation process. Perry $(1980,1983)$.

2. See Eckstein and Wilson (1962) for a discussion of the 1950s and 1960s. For a later study analyzing the variation in union-nonunion wages, see Perry (1967). In Daniel Mitchell's view, wage norms are present only in union wage behavior; see Mitchell (1985). 
our focus to the union wage premium. Because there are no government data on wage premiums and because there is no way even to track union and nonunion relative wage increases before 1976, we first construct and evaluate relative wage and wage premium measures. What the data show is that the union premium follows a pattern, with long periods of yearto-year increases followed by long periods of year-to-year declines. During much of the 1960s and 1980s, union wage moderation was reflected in consistent annual decreases in the premium. During the 1950 s and 1970s, by contrast, the premium showed a trend of annual increases. In this paper, we use the term "wage norm shift" to refer to these global changes in the direction of the premium. ${ }^{3}$ An important question that we seek to answer is whether the 1980s norm of declining premiums is about to shift. We believe that a historically low premium today would increase the likelihood of a norm shift in the near term, hence increasing wage pressure on inflation rates. The evidence, though, is that union premiums remain high enough to preclude a norm shift.

We next turn to the broader issue of changes in the health of the union sector, including the degree of management acceptance of unions. We analyze union employment shares, strike activity, allegations of employer unfair labor practices and decertification elections, and evidence of any changes in the direction of labor law. Significant changes in these variables are likely to precede wage norm shifts. Again, the evidence suggests continued union wage moderation.

Using our newly constructed union and nonunion wage series, we then present a more traditional analysis of the short-term outlook for wages. The regression equations we estimate are modeled after aggregate equations developed by George Perry and Robert Gordon. Because of data limitations, we do not attempt to explain how wage norms are determined. The institutional variables that are likely to be important in capturing shifts in union norms are not available in a form that can be used in wage change equations. The equations, however, can be used to project future union and nonunion wage behavior as long as the norm does not change-as our analysis concludes it will not.

3. Wage norms are typically defined in terms of a nominal wage series, whether aggregate or sector-specific. Defining the norm as a characteristic of the wage premium series is thus a different use of the term. However, as we shall show, shifts in the premium norms correlate closely, both conceptually and empirically, with shifts in Perry norms. 


\section{Aggregate, Union, and Nonunion Wage Increases}

In the past few years wage and compensation measures, although still rising slowly by standards of the 1970 s, have begun to accelerate. As table 1 shows, between 1980-81 and 1986, the rate of growth of aggregate employment cost index (ECI) compensation trended lower, with a cyclical low of 3.2 percent in 1986. As of the second quarter of 1989 , the annual change stood at 4.5 percent. ${ }^{4}$ The change in ECI wages mirrors that of compensation. From a high of 9.0 percent in 1980, the rate-ofchange series reached a low of 3.1 percent in 1986. It has now reached 4.1 percent.

The percent change in the average hourly earnings index (HEI) gives a less inflationary reading of labor market pressures. This series not only troughed at a lower level than did the change in ECI wages, falling to 2.4 percent in 1986, but it has also been running well below the ECI wage change series since 1983. As of the fourth quarter of 1988, the HEI index increase was up, but only to 3.4 percent, 0.7 percentage point below ECI wage increases.

The discrepancy between the two is large enough to require an explanation. The HEI and ECI series differ in three respects. First, the ECI controls for compositional shifts across two-digit industries and three-digit occupations (within firms and then aggregated at the one-digit level), while the HEI index controls only for industry shifts. Second, the HEI excludes nonproduction workers in the goods-producing industries and nonsupervisors in the service-producing sectors, populations that are included in the ECI. Third, the HEI sample is much larger than the ECI sample.

Acknowledging the gap between the two series, the Bureau of Labor Statistics (BLS) has published an ECI series based on the HEI worker population-that is, production and nonsupervisory workers. The new series, designated ECI-HEI and shown in the fourth column of the table, is considerably closer to the broader ECI than to the HEI, suggesting

4. The ECI wage is currently a better measure of underlying labor market pressures than is ECI compensation. In particular, compensation has been pushed higher by factors largely irrelevant to labor market conditions such as higher OASDI tax rates and oversized increases in health costs. 
Table 1. Indexes of Wage and Compensation Growth, 1980-89

Percent change

\begin{tabular}{|c|c|c|c|c|c|}
\hline \multirow[b]{2}{*}{ Year } & \multicolumn{2}{|c|}{$\begin{array}{c}\text { Employment cost index- } \\
\text { private }\end{array}$} & \multirow{2}{*}{$\begin{array}{c}\text { Hourly } \\
\text { earnings } \\
\text { index }\end{array}$} & \multirow[b]{2}{*}{$\begin{array}{l}\text { ECI-HEI } \\
\text { basis }^{\mathrm{b}}\end{array}$} & \multirow[b]{2}{*}{$\begin{array}{l}\text { Union wag } \\
\text { adjustment }\end{array}$} \\
\hline & Compensation & $\begin{array}{l}\text { Wages and } \\
\text { salaries }\end{array}$ & & & \\
\hline 1980:4 & 9.8 & 9.0 & 9.6 & 9.4 & 9.9 \\
\hline 1981:4 & 9.8 & 8.8 & 8.3 & 9.0 & 9.5 \\
\hline $1982: 4$ & 6.4 & 6.3 & 6.1 & 6.2 & 6.8 \\
\hline $1983: 4$ & 5.7 & 5.0 & 4.0 & 4.9 & 4.0 \\
\hline $1984: 4$ & 4.9 & 4.1 & 2.9 & 3.9 & 3.7 \\
\hline $1985: 4$ & 3.9 & 4.1 & 3.1 & 4.0 & 3.3 \\
\hline 1986:4 & 3.2 & 3.1 & 2.4 & 2.7 & 2.3 \\
\hline 1987:4 & 3.3 & 3.3 & 2.6 & 3.3 & 3.1 \\
\hline 1988:4 & 4.9 & 4.1 & 3.4 & 4.2 & 2.6 \\
\hline 1989:1 & 4.6 & 4.2 & n.a. & 4.6 & 2.7 \\
\hline 1989:2 & 4.5 & 4.1 & n.a. & 4.1 & 2.8 \\
\hline
\end{tabular}

Sources: ECI data from Bureau of Labor Statistics (1989b). HEI from BLS data. Wage adjustment data for 198088 from Current Wage Developments, March 1989, table 1; for 1989, from Monthly Labor Review, October 1989, table 28 .

n.a. Not available. The hourly earnings index is no longer published by the BLS.

a. All values measure the change in a given quarter from four quarters earlier, except for wage adjustments for 1980-88, which measure average annual changes.

b. The $\mathrm{ECl}$ for production and nonsupervisory workers.

c. Total effective wage adjustments prorated across all workers under contracts covering 1,000 or more workers. Excludes lump-sum and profit-sharing payments, overtime, and nonwage benefits.

that the major difference between the HEI and the broader ECI comes more from the method of adapting for compositional shifts than from differences in sample definitions. On this basis, we conclude that the ECI wage's 4.1 percent rate of increase is a more accurate reading of the rate of economywide wage change than is the HEI index's 3.4 percent rate.

The primary source of wage moderation during the 1980s has been the union sector. Union wage changes represented by the BLS series on effective wage adjustments in major collective bargaining contracts (major agreements) are shown in the final column of table 1. Major agreements wage gains were 2.8 percent in the second quarter of 1989 , much lower than the 4.1 percent rate for ECI wages, and only barely above the 2.6 rate for all of 1988 .

Union wage data, however, can yield different answers depending on the precise question asked. The 2.8 percent rate in the second quarter of 1989 is a backward-looking number in that it includes increases in 
Table 2. Wage Trends in Current Settlements ${ }^{\mathrm{a}}$

Percent change

\begin{tabular}{|c|c|c|c|c|c|c|}
\hline \multirow[b]{2}{*}{ Type of contract } & \multicolumn{4}{|c|}{ Change from four quarters earlier } & \multicolumn{2}{|c|}{$\begin{array}{l}\text { Change from } \\
\text { last quarter }\end{array}$} \\
\hline & $1987: 4$ & 1988:4 & 1989:1 & 1989:2 & 1989:1 & 1989:2 \\
\hline All contracts & & & & & & \\
\hline $\begin{array}{l}\text { Over-life-of- } \\
\text { contract }\end{array}$ & 2.1 & 2.4 & 2.5 & 2.9 & 3.1 & 3.3 \\
\hline First-year & 2.5 & 2.5 & 2.7 & 3.2 & 3.2 & $3.9^{\mathrm{c}}$ \\
\hline $\begin{array}{l}\text { Contracts without } \\
\text { COLA clauses over } \\
\text { life of contract }\end{array}$ & 2.5 & 2.8 & 2.9 & 3.2 & 3.2 & 3.4 \\
\hline
\end{tabular}

Source: Current Wage Developments, September 1989, tables 17 and 18.

a. The data are wage adjustments for contracts signed during each quarter. They differ from the union wage adjustment series in table 1, which shows adjustments across all workers for contracts then in effect. The data are contractual wage increases without any contingent payments such as COLA clauses.

b. At annual rates.

c. First-year increases for 1989:2 include the restoration of the wage reductions in major steel contracts.

contracts negotiated in 1988, 1987, and even 1986. Settlement data, which are forward looking, show a higher rate of wage change and a more marked acceleration. As shown in table 2, over-life-of-contract increases have moved from an average of 2.1 percent in 1987 to 3.3 percent in 1989:2. Moreover, because settlement data do not include contingent payments such as cost-of-living adjustments (COLAs), actual increases in the most recent settlements will be greater than 3.3 percent. For contracts without COLA clauses (not a random sample of all BLS covered contracts), the rate of increase is now 3.4 percent.

Still another piece of evidence that union wage increases are accelerating is the decline in the number of contracts with bonuses. Bonuses have primarily been used in contracts with wage cuts or very low wage increases. In 1987, 52 percent of workers with newly signed contracts received bonuses. In 1988 the share of workers receiving bonuses was down to 28 percent. As of the first half of 1989 , only 25 percent had bonuses. $^{5}$

For a final look at union wage trends, we decompose collective bargaining contracts into three categories: those with wage increases, those with no change, and those with wage decreases. As shown in table 3 , the share of workers in the major agreement sample who are taking

5. Bonuses are classified by the BLS as compensation rather than wages. There is some evidence that lump-sum payments may continue, taking on aspects of profit-sharing. See Bell and Neumark (1989). 
Table 3. Contract Settlement Data: Effective Wage Adjustments, 1981-88 ${ }^{a}$

Percent

\begin{tabular}{|c|c|c|c|c|c|c|c|}
\hline \multirow[b]{2}{*}{ Year } & \multirow{2}{*}{$\begin{array}{c}\begin{array}{c}\text { All con- } \\
\text { tracts }\end{array} \\
\begin{array}{c}\text { Wage } \\
\text { change }\end{array}\end{array}$} & \multicolumn{2}{|c|}{$\begin{array}{l}\text { Contracts with wage } \\
\text { increase }\end{array}$} & \multirow{2}{*}{$\begin{array}{c}\begin{array}{c}\text { Contracts } \\
\text { with no } \\
\text { change }\end{array} \\
\text { Percent } \\
\text { of con- } \\
\text { tracts }\end{array}$} & \multicolumn{2}{|c|}{$\begin{array}{c}\text { Contracts with wage } \\
\text { decrease }\end{array}$} & \multirow{2}{*}{$\begin{array}{c}\text { New con- } \\
\text { tracts } \\
\text { with } \\
\text { wage de- }^{\text {crease }} \\
\begin{array}{c}\text { Percent } \\
\text { of con- } \\
\text { tracts }\end{array}\end{array}$} \\
\hline & & $\begin{array}{c}\text { Whage } \\
\text { change }\end{array}$ & 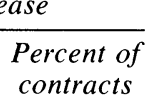 & & $\begin{array}{l}\text { Wage } \\
\text { change }\end{array}$ & $\begin{array}{l}\text { Percent } \\
\text { of con- } \\
\text { tracts }\end{array}$ & \\
\hline 1981 & 9.5 & 9.9 & 97.1 & 1.6 & -13.3 & 1.3 & 1.3 \\
\hline 1982 & 6.8 & 7.2 & 93.9 & 5.8 & -7.2 & 0.3 & 0.3 \\
\hline 1983 & 3.9 & 5.7 & 78.3 & 15.4 & -7.7 & 6.3 & 6.1 \\
\hline 1984 & 3.7 & 4.7 & 82.6 & 15.3 & -7.4 & 2.1 & 1.7 \\
\hline 1985 & 3.3 & 4.2 & 79.3 & 19.5 & -2.5 & 1.2 & 1.0 \\
\hline 1986 & 2.3 & 3.4 & 78.5 & 17.7 & -7.9 & 3.8 & 3.5 \\
\hline 1987 & 3.1 & 3.8 & 83.4 & 15.1 & -7.9 & 1.5 & 1.3 \\
\hline 1988 & 2.6 & 3.4 & 77.7 & 21.2 & -4.4 & 1.0 & 0.5 \\
\hline
\end{tabular}

Source: BLS data supplied by Harriet Weinstein.

a. Effective wage adjustments do not include lump-sum payments or profit-sharing payments. Adjustments in shift differentials are included, with the exception of overtime.

b. Includes only contracts with decreases that were signed during the particular period.

wage cuts has declined from a peak of 6.3 percent in 1983 to 1.0 percent in 1988. Moreover, only 0.5 percent of workers signing new contracts in 1988 took wage cuts. Although the decline in the number of workers taking wage cuts has been absorbed by the "no change" column, the shift is indicative of an end to the period of effective nominal wage cuts.

For union workers receiving increases, the increase was 3.4 percent in 1988, compared with 2.6 percent for all union workers. Moreover, contracts that included positive wage adjustments were bunched near the 3 percent to 4 percent level. Such data suggest two union sectors: one in which wages are not increasing and another in which wages are growing between 3 percent and 4 percent, at or just below the rate of growth of economywide wages.

A key question is what happens next in the sectors that have progressed from wage cuts to zero increases. Certainly, wage cuts and zero increases are hardly the equilibrium rate of change. ${ }^{6}$

6. The restoration of wage cuts appears as a wage increase. Although the magnitude of wage cuts that have not been restored is unknown, it is likely that there will be a spike in union wage increases over the next few years as more cuts are restored. 
The recently negotiated contract between the United Steel Workers and Bethlehem Steel gives the latest, although very partial, answer to the question. The steel contract restores a 8.09 percent wage cut agreed to in 1986. In addition, it calls for annual increases of approximately 4.55.0 percent a year over the life of the contract, exclusive of the restored cuts. $^{7}$

This steel settlement marks the sharpest acceleration in union wages. But, unlike in past decades, the steel settlement will not set a pattern to be copied automatically by other unions. It is thus an open question whether the contract's 4.5-5.0 percent annual increase is an outlier or a harbinger of things to come. ${ }^{8}$

In summary, wage changes in the union sector are clearly lagging those in the nonunion sector. Although union wage adjustments are at a modest 2.8 percent rate when prorated across all workers, current settlements show a higher rate, equal to 3.4 percent (for contracts without COLA clauses). The recent Bethlehem Steel contract is even higher, with wage increases in the 4.5-5.0 percent rate. These latter figures are estimates of what currently negotiated settlements will be paying out in 1989, 1990, and 1991.

\section{Union Wage Premiums and Relative Wage Changes}

To understand the recent pattern of union wage moderation, it is important to place it in a broader and more detailed historical record of union and nonunion wages. To do so, we turn to two complementary sets of data.

The first are the annual, cross-sectional Current Population Surveys (CPS), which began in 1973. The surveys allow us to estimate directly union wage premiums, that is, the wage gap between union workers and comparably skilled nonunion workers. These data also permit disaggregated industry premium calculations. The limitation of the CPS, particularly for pre-1983 samples, is that the confidence intervals around the

7. The Bethlehem Steel agreement with the United Steelworkers is covered in Daily Labor Report, May 10, 1989, No. 89, F-1 to F-3. This contract comports with other recent steel contracts. Steel contracts dominate the 1989:2 figures of table 2 .

8. We do not deal explicitly with spillovers among unions or between the union and nonunion sectors. See Flanagan (1986). 
premium estimates are too wide to make a statement about year-to-year changes reliable.

The second data set is the quarterly establishment HEI data, which began in 1976. These allow for year-to-year comparisons but do not allow for a calculation of premiums for comparably skilled workers. In this section we combine the two data sets to calculate new wage premium series back to the 1950 s.

\section{Estimates from the Current Population Survey}

The CPS data sample includes observations on full-time workers' usual weekly earnings and hours, occupation, education, industry, union status, region and city size of residence, and demographic features. In this format, the skill, demographic, and locational variables are used to define wage comparability. These variables control for features of the individual who holds the job and can be broadly viewed as "skill descriptive." Conversely, a set of union status variables interacted with (one-digit) industry dummies can be used to define wage differences that are not due to the skill-descriptive variables.

$$
\begin{aligned}
\operatorname{Ln}(W)=a_{0} & +\sum_{k=1}^{K} a_{k} \text { SKILL VARIABLES } \\
& +\sum_{i=1}^{I} b_{1, i} \text { NONUNION }_{i}+b_{2, i} \text { UNION }_{i},
\end{aligned}
$$

where $W$ is the wage, $N O N U N I O N_{i}$ and $U_{N I O N_{i}}$ are dummies representing union status in industry $i$, and $K$ and $I$ are the total number of skill variables and industries, respectively. The union wage premiums for each industry for a particular year are then calculated as

$$
\text { PREMIUM }_{i}=\left[\exp \left(P_{i}\right)-1\right] \times 100,
$$

where $P_{i}=\hat{b}_{2, i}-\Sigma_{i=1}^{I} \hat{b}_{1, i} W_{N U, i}$ and $W_{N U, i}$ is the nonunion industry $i$ 's average share of total private nonunion employment over 1973-87. The wage premium is thus calculated as the union premium for each industry over and above the wage of nonunion workers of comparable skill (as defined by the control variables) across the private economy. ${ }^{9}$

9. The traditional approach is to compare union workers in each industry with nonunion workers in the same industry. We prefer a comparison of union wages by industry with economywide nonunion wages. See Linneman and Wachter (1986). 
Table 4. CPS Estimated Union Premium for Alternative Union Sectors, 1973-88, Selected Years ${ }^{\mathrm{a}}$

Percent

\begin{tabular}{lcccc}
\hline Year & Aggregate & $\begin{array}{c}\text { Aggregate } \\
\text { minus } \\
\text { construction }^{\mathrm{b}}\end{array}$ & $\begin{array}{c}\text { Industrial } \\
\text { sector }^{\text {d }}\end{array}$ & $\begin{array}{c}\text { Service } \\
\text { sector }^{\mathrm{e}}\end{array}$ \\
\hline $1973-74$ & 24.4 & 19.8 & 22.8 & 10.2 \\
$1976-77$ & 28.5 & 24.5 & 28.0 & 13.2 \\
1983 & 27.7 & 24.3 & 28.8 & 9.7 \\
1985 & 28.7 & 25.4 & 30.4 & 9.7 \\
$1987-88$ & 28.1 & 24.8 & 29.5 & 9.8 \\
\hline
\end{tabular}

a. Table presents estimates based on equations 1 and 2 in the text. In each case the nonunion sector is a fixedweight of all private nonunion industry sectors. Union industry sector weights are also fixed across years. Premium estimates are for the Current Population Survey sample restricted to full-time, nonagricultural workers, minus executives and professionals. The estimating equations include controls for occupation, region, race-gender, usual overtime, the local unemployment rate, education, experience, squared education and experience, and experience interactive with gender.

b. All private sector union industry sectors.

c. All private sector union industry sectors, but with union construction removed.

d. Contains mining, durable manufacturing, nondurable manufacturing, and transportation and public utilities union sectors.

e. Contains retail trade, wholesale trade, finance, and services union sectors.

The resulting union wage premiums for selected years from 1973 through 1988 appear in table $4 .{ }^{10}$ To address the difficulties of making year-to-year comparisons we have averaged the years 1973-74, 197677 , and 1987-88 to provide more robust premium estimates for those years. (The choice of years will be made clearer below.) The aggregate union wage premium, shown in the first column, is calculated as a fixedweight series in which the employment weights for aggregating industry premiums are held constant at period means.

The first finding is that the union wage premium is currently 28.1 percent, roughly equal to that in $1976-77$, but 4.1 percent higher than that in 1973-74, the first two years when CPS estimates were available. A second finding is that premium trends differ considerably across industries. Because we have dealt with this topic in depth elsewhere, we only summarize the results here ${ }^{11}$ In the high-premium, highly unionized industries (with the exception of construction), premiums increased substantially over the sample period. Hence, an industrial union premium (third column) that stood at 22.8 percent in $1973-74$ is 29.5 percent in 1987. On the other hand, in the weakly unionized sectors, premiums

10. For a review of the literature on union wage premiums see Lewis (1986).

11. See Linneman, Wachter, and Carter (1990). 
remained low. As the fourth column shows, the premium of 9.8 percent in 1987 is close to the 10.2 percent premium of $1973-74 . .^{12}$

Two results from the CPS premium analysis are important for the next section. The first is the need to look at the union premium in a historical context. Although the union premium has decreased during the 1980s, it is still above its 1973-74 level. The second result is the importance of interindustry differences. Given our topic of unions as a possible source of cost-push pressure, we need to isolate the industrial sectors in which already high premiums (in 1973) trended higher through the 1970 s and early 1980 s.

\section{ECI Union and Nonunion Wages, 1976-88}

The easiest place to begin an analysis of a time series of unionnonunion wages is 1976, the year the ECI union and nonunion series became available. As has been widely noted, these series, shown in the first two columns of table 5, illustrate that union wage increases outpaced nonunion increases every year between 1976 and 1982 and that the reverse has been true every year since. Indeed, the period of union wage moderation since 1983 has now entirely reversed the union wage gains of 1976-82. In terms of 1976 and 1988 endpoints, these results are similar to those shown in table 4 . The premium in 1976-77 is similar to the premium in 1987-88. ${ }^{13}$

12. A simple categorization into industrial and nonindustrial union sectors, however, does not capture all differences across industries in premium trends. For example, the premium in nondurable manufacturing, the lowest in the industrial sector, is approximately equal to the premium in wholesale trade, the highest in the nonindustrial sector. Moreover, the premiums in wholesale and retail trade did increase somewhat during 1973-87. In addition, construction is an outlier in the industrial sector. Although it had the highest premium in 1973-74, the premium trended downward after 1973.

13. In terms of the time series aspects of the CPS, a puzzling result is that the decline in premiums during the late 1980 s appears to be minor, especially compared with the decline in the ECI premium. The CPS premiums peak in 1985 (instead of 1983) and the decline from 1985 to 1987 is relatively small. There are explanations for this, including the size of the confidence interval for annual estimates, but none is entirely satisfactory. One explanation may be found in the disparities in the rates of change of occupational wages during the 1980s. The CPS has occupational control variables so that, other things being equal, blue-collar union workers are compared with blue-collar nonunion workers. The same is true for the education control variable. Based on ECI occupational wage changes, it is clear that managerial and professional occupations received by far the highest occupational wage increases whether union or nonunion. Hence, it is possible that the 
The ECI union-nonunion series can be improved on as a measure of union wage differentials. Many nonunion workers in the ECI series, for example, are in occupations that are not comparable to those of union workers. In particular, executives and professionals represent approximately 33 percent of all private ECI industry workers. ${ }^{14}$ Our preferred base group, denoted “nonunion-nonexecutive," is constructed by taking the ECI nonunion series and purging it of a fixed-weight contribution from the ECI executives and ECI professionals series.

For our purposes, the major agreements series is also preferable to the ECI union series. The major agreements data cover the 1960s, an advantage on which we rely heavily below. The series also is better linked to the collective bargaining data in tables 2 and 3 and has an advantage over the ECI union series in terms of compositional shift properties. ${ }^{15}$

In calculating a union-nonunion wage premium for 1976-89, our preferred measure thus has the major agreements series as the union numerator and the ECI nonunion-nonexecutive series as the denominator. In the third column we show our preferred union wage premium series. The premium is 31.0 percent in 1976 , increasing to 40.7 percent in 1982 and then declining to 31.3 percent in the first quarter of 1989.

Given the availability of the ECI data back to 1976, it would be easy

nonunion work force most directly comparable to the union work force received even lower increases than our ECI nonexecutive series suggests. Another explanation may be found in the way workers are laid off in declining industries. Assuming that older workers have the highest premium, layoffs based on seniority have a compositional shift toward higher premiums.

14. "Relative Importance of Employment Cost Index Components,'” Office of Compensation and Working Conditions, Bureau of Labor Statistics, February 1989.

15. The ECI union and, for that matter, the ECI nonunion series are not fixed-weight series. The fixed weights of the ECI sample extend only to occupation and industry. For our purposes, this is more of a problem for the ECI union than for the ECI nonunion series. There have been major industrial shifts in the union sector toward service (industry and occupation) workers so that the ECI union series increasingly reflects developments in the union-service sectors. (However, since wage changes are calculated for each category and the aggregation is across wage changes, the more severe compositional problem found in the HEI index is not created. In the HEI index, a shift toward low-wage occupations would cause the HEI to show a negative change, even if all wages remained unchanged.)

The major agreements series overweights the industrial unions because it excludes union contracts covering fewer than 1,000 workers, but this overweighting is likely to cause less distortion than the shifting weights in the ECI union. Fortunately, for the period during which the ECI union is available, little rests on which is chosen. 
Table 5. Wage Change and Alternative Union Premium Series, 1947-89

Percent

\begin{tabular}{|c|c|c|c|c|c|}
\hline \multirow[b]{3}{*}{ Year } & \multirow{2}{*}{\multicolumn{2}{|c|}{ Rate of wage change }} & \multicolumn{3}{|c|}{ Premium series $^{\mathrm{a}}$} \\
\hline & & & \multirow{2}{*}{$\begin{array}{c}\text { Major } \\
\text { agreements- } \\
\text { ECI } \\
\text { nonunion- } \\
\text { nonexecutive }^{\mathrm{b}}\end{array}$} & \multirow{2}{*}{$\begin{array}{l}\text { Major } \\
\text { agreements- } \\
\text { HEI low- } \\
\text { union }^{c}\end{array}$} & \multirow{2}{*}{$\begin{array}{l}\text { HEI high- } \\
\text { union-HEI } \\
\text { low-union }^{\mathrm{d}}\end{array}$} \\
\hline & $\begin{array}{c}\text { ECI } \\
\text { union }\end{array}$ & $\begin{array}{c}\text { ECI } \\
\text { nonunion }\end{array}$ & & & \\
\hline $\begin{array}{l}1947 \\
1950\end{array}$ & $\begin{array}{l}\text { n.a. } \\
\text { n.a. }\end{array}$ & $\begin{array}{l}\text { n.a. } \\
\text { n.a. }\end{array}$ & $\begin{array}{l}\text { n.a. } \\
\text { n.a. }\end{array}$ & $\begin{array}{l}\text { n.a. } \\
\text { n.a. }\end{array}$ & $\begin{array}{l}21.8 \\
24.2\end{array}$ \\
\hline $\begin{array}{l}1955 \\
1956 \\
1957 \\
1958 \\
1959\end{array}$ & $\begin{array}{l}\text { n.a. } \\
\text { n.a. } \\
\text { n.a. } \\
\text { n.a. } \\
\text { n.a. }\end{array}$ & $\begin{array}{l}\text { n.a. } \\
\text { n.a. } \\
\text { n.a. } \\
\text { n.a. } \\
\text { n.a. }\end{array}$ & $\begin{array}{l}\text { n.a. } \\
\text { n.a. } \\
\text { n.a. } \\
\text { n.a. } \\
\text { n.a. }\end{array}$ & $\begin{array}{l}\text { n.a. } \\
\text { n.a. } \\
\text { n.a. } \\
\text { n.a. } \\
26.5\end{array}$ & $\begin{array}{l}28.2 \\
28.9 \\
29.7 \\
31.4 \\
32.6\end{array}$ \\
\hline $\begin{array}{l}1960 \\
1961 \\
1962 \\
1963 \\
1964\end{array}$ & $\begin{array}{l}\text { n.a. } \\
\text { n.a. } \\
\text { n.a. } \\
\text { n.a. } \\
\text { n.a. }\end{array}$ & $\begin{array}{l}\text { n.a. } \\
\text { n.a. } \\
\text { n.a. } \\
\text { n.a. } \\
\text { n.a. }\end{array}$ & $\begin{array}{l}\text { n.a. } \\
\text { n.a. } \\
\text { n.a. } \\
\text { n.a. } \\
\text { n.a. }\end{array}$ & $\begin{array}{l}26.7 \\
26.5 \\
25.0 \\
24.5 \\
23.5\end{array}$ & $\begin{array}{l}32.6 \\
32.5 \\
31.4 \\
30.6 \\
29.4\end{array}$ \\
\hline $\begin{array}{l}1965 \\
1966 \\
1967 \\
1968 \\
1969\end{array}$ & $\begin{array}{l}\text { n.a. } \\
\text { n.a. } \\
\text { n.a. } \\
\text { n.a. } \\
\text { n.a. }\end{array}$ & $\begin{array}{l}\text { n.a. } \\
\text { n.a. } \\
\text { n.a. } \\
\text { n.a. } \\
\text { n.a. }\end{array}$ & $\begin{array}{l}\text { n.a. } \\
\text { n.a. } \\
\text { n.a. } \\
\text { n.a. } \\
\text { n.a. }\end{array}$ & $\begin{array}{l}22.1 \\
20.3 \\
19.1 \\
18.3 \\
17.6\end{array}$ & $\begin{array}{l}28.0 \\
26.3 \\
24.0 \\
23.5 \\
22.5\end{array}$ \\
\hline $\begin{array}{l}1970 \\
1971 \\
1972 \\
1973 \\
1974\end{array}$ & $\begin{array}{l}\text { n.a. } \\
\text { n.a. } \\
\text { n.a. } \\
\text { n.a. } \\
\text { n.a. }\end{array}$ & $\begin{array}{l}\text { n.a. } \\
\text { n.a. } \\
\text { n.a. } \\
\text { n.a. } \\
\text { n.a. }\end{array}$ & $\begin{array}{l}\text { n.a. } \\
\text { n.a. } \\
\text { n.a. } \\
\text { n.a. } \\
\text { n.a. }\end{array}$ & $\begin{array}{l}20.7 \\
24.0 \\
24.3 \\
25.7 \\
27.9\end{array}$ & $\begin{array}{l}21.2 \\
22.3 \\
24.9 \\
26.3 \\
26.9\end{array}$ \\
\hline $\begin{array}{l}1975 \\
1976 \\
1977 \\
1978 \\
1979\end{array}$ & $\begin{array}{r}\text { n.a. } \\
8.1 \\
7.6 \\
8.0 \\
9.0\end{array}$ & $\begin{array}{l}\text { n.a. } \\
6.8 \\
6.6 \\
7.6 \\
8.5\end{array}$ & $\begin{array}{l}\text { n.a. } \\
31.0 \\
32.8 \\
33.2 \\
33.6\end{array}$ & $\begin{array}{l}30.1 \\
32.0 \\
32.7 \\
32.7 \\
34.6\end{array}$ & $\begin{array}{l}30.4 \\
33.7 \\
35.3 \\
35.9 \\
37.2\end{array}$ \\
\hline $\begin{array}{l}1980 \\
1981 \\
1982 \\
1983 \\
1984\end{array}$ & $\begin{array}{r}10.9 \\
9.6 \\
6.5 \\
4.6 \\
3.4\end{array}$ & $\begin{array}{l}8.0 \\
8.5 \\
6.1 \\
5.2 \\
4.5\end{array}$ & $\begin{array}{l}36.9 \\
39.2 \\
40.7 \\
39.8 \\
39.6\end{array}$ & $\begin{array}{l}36.2 \\
37.3 \\
37.5 \\
35.1 \\
35.5\end{array}$ & $\begin{array}{l}38.0 \\
39.9 \\
40.4 \\
39.3 \\
39.8\end{array}$ \\
\hline $\begin{array}{l}1985 \\
1986 \\
1987 \\
1988\end{array}$ & $\begin{array}{l}3.1 \\
2.0 \\
2.6 \\
2.2\end{array}$ & $\begin{array}{l}4.6 \\
3.5 \\
3.6 \\
4.5\end{array}$ & $\begin{array}{l}37.4 \\
35.9 \\
35.8 \\
32.6\end{array}$ & $\begin{array}{l}35.6 \\
34.6 \\
34.7 \\
32.5\end{array}$ & $\begin{array}{l}40.1 \\
38.7 \\
37.0 \\
35.0\end{array}$ \\
\hline $\begin{array}{l}\text { 1989:1 } \\
1989: 2\end{array}$ & $\begin{array}{l}2.5 \\
2.6\end{array}$ & $\begin{array}{l}4.8 \\
4.6\end{array}$ & $\begin{array}{l}31.3 \\
\ldots .\end{array}$ & $\begin{array}{l}31.0 \\
\ldots .\end{array}$ & $\begin{array}{l}32.8 \\
\ldots .\end{array}$ \\
\hline
\end{tabular}

n.a. Not available.

a. Results presented are ratios of the specified union and nonunion data, less a benchmark factor. The factor for each premium series equals the difference between the average actual wage differential from 1973-75 and the average estimated wage premium from equations 1 and 2 over the period 1973-75.

b. The major agreements union series are effective mean or median (before 1968) wage adjustments (see table 1 , note c). Prior to 1966 , construction, finance, and services were excluded from this series.

c. Low union density industries (listed by percent union in ascending order): finance, insurance, and real estate; service; crude and gas mining; retail trade; textile manufacturing; and wholesale trade. Prior to 1964, service industry wages are assumed to remain a constant (1964) proportion of average wages in the rest of the nonunion category. d. High union density industries (listed by percent union in descending order): railroad; coal mining; primary metals; transportation equipment manufacturing; paper; telephone communications; stone, clay, and glass; metal mining; petroleum refining; food products; fabricated metals; rubber; machinery; electrical equipment; chemicals; construction; tobacco; and electric power. 
to start an analysis of union wages with 1976. Indeed, the literature on union wages frequently uses 1976 as a starting point because of the need for data consistency. For the reasons noted above, however, it would also be misleading. The finding that union premiums today are at 1976 levels is technically correct, but a broader conclusion that today's premium is in line with past premiums over a longer time period is incorrect. It is to this topic that we now turn.

\section{Tracking Relative Wages Back to the 1950s}

To analyze the variation in union wage premiums before 1973, alternative data sources must be introduced. To provide a continuous measure of union wage changes back to 1959, we splice a series for median wages (available back to 1959) onto the series for effective mean wage adjustments (available back only to 1968). Before 1959 for a union series and before 1976 for a nonunion series, we rely on average hourly earnings data. Because these series are not divided into union and nonunion observations, we treat the sectors with very high percentages of union employment as representative of union wage trends and the sectors with very low percentages of union employment as representative of nonunion wage trends. To be comparable with the ECI and CPS figures, the series are benchmarked off CPS union wage premiums for $1973-75.16$

The fourth column of table 5 shows the resulting union wage premium series based on the major agreements series as the numerator and the HEI low-union series as the denominator. The series begins at 26.5 in 1959. During the $1960 \mathrm{~s}$, nonunion wage gains outpaced union wage gains, with the premium declining from 26.7 in 1960 to a low of 17.6 in 1969. Between 1969 and 1976 (when the ECI tracking becomes available) the union wage premium regains and then surpasses the 1959 level. Between 1976 and 1989 the new series tracks the major agreements-ECI nonunionnonexecutive. This series shows that the union premium in 1989 is above

16. To control for industrial shifts, we adopt fixed (at midsample) weights for the union and nonunion series. Since our goal is to trace union premiums back through the $1950 \mathrm{~s}$, wage series beginning later than 1947 are omitted. The resulting omissions, however, are not a serious problem given the evidence from the CPS. The industrial sectors highlighted in the CPS results are the ones with the available wage series. In the nonunion sector, the main problem is that the service sector has wage data only after 1963 . Since the inclusion of services is important, this series is spliced into the nonunion series. 
the level existing in 1960 , prior to the 1960 s decade of union wage moderation.

In the final column, we use the highly unionized HEI series as the numerator with the same nonunion denominator as in the fourth column. ${ }^{17}$ Given longer time series, we are able to track a union-nonunion premium back to 1947 and to add another premium cycle. The premium increases throughout the later 1940s and all of the 1950s. From a low of 21.8 percent in 1947, the premium grows to 32.6 percent by 1959 .

\section{Some Preliminary Conclusions}

An analysis of these series helps answer the question of whether wage developments after 1989 are likely to be a replay of developments after 1969. If the union wage premium is a guide, the answer is no. In 1969 the union wage premium was close to its series low, having reversed the entire increase from 1947. In 1989, the premium remains much closer to series highs than lows. The key to the high premiums existing today is that the increase in the premium from 1969 to 1983 was much greater than the increase of the 1950s that preceded the decline of the 1960s. Hence, if history repeats itself, 1989 should not be the start of a new inflationary trend in union wages. The premium is too high.

Given a division of all industries with wage series, our union series includes the most heavily unionized groups, while the nonunion series includes the least heavily unionized. The middle group was omitted from both. The level of each group does comport with the hypothesis that more strongly unionized industries will achieve union wage premiums. Hence, for the most strongly unionized series, the industry relative wage in 1975 is 20.7 percent higher than the average industry wage. Premiums in the next heavily unionized sector are approximately half those of the most unionized. Finally, the least unionized group has the lowest wage premium. In 1975, its wage is 13.5 percent below the average wage for comparably skilled workers throughout the economy.

17. The premium series in the final column does not include construction in the union sector. We also constructed a union premium series that includes construction in the union base. A comparison of the two locates the period when the construction union premium diverged from the other industrial union premiums. The series excluding construction begins 4.5 percentage points higher than the series with construction. In the late $1960 \mathrm{~s}$, the gap begins to close, and, by 1973, the premium series including construction is 0.7 percentage point higher than the series exluding construction. Hence, the construction premium increases immediately before the starting date of our first CPS survey. This suggests that the construction unions were the leaders in the timing of the premium increase. To date, they have also been the leaders in the premium decline. 
But history does not always repeat itself, and, moreover, a high premium hardly settles the next move in the premium. After all, the ability of unions to maintain a high premium may be indicative of an underlying core of strength that could reestablish itself in an environment of low unemployment rates. To see whether premiums remain high because of union strength or in spite of weakness, we must look elsewhere, to indicators of union health and relative bargaining power.

\section{Other Indicators of Union Economic Power}

Other indicators of the near-term direction of the union premium include four important indexes of union power: union employment shares, strike activity, management opposition to unions, and labor law.

\section{Union Employment Shares and Concession Bargaining}

In the textbook labor economics model, the economic power of unions is tied to the degree to which they organize workers in the relevant product market. The first three columns of table 6 track three measures of the degree of unionization. The first, union membership as a percentage of total employment, peaks in the early 1950s, with more than one in three workers belonging to unions. That percentage trends downward, but during the 1969-77 run-up in the wage premium one in four workers is still a union member. The percentage falls at an accelerating rate to one in five from 1978 to 1982 , a period of a stable, but slightly rising, premium. As the premium then declines slightly, membership falls further to one in eight in 1988.

Unlike the union percentages, which trend downward in the 1950s, the second measure of unionization, absolute number of union members (second column), does not peak until the early 1970s and remains very close to that peak value in 1977 . Once the absolute number of union members begins to decline, however, it declines sharply, dropping more than 25 percent between 1979 and $1988 .{ }^{18}$

The ability of unions to influence political and legal outcomes involving unions may depend on their representation in the overall labor force.

18. For a discussion of the causes of the decline in union membership, see Edwards and Swaim (1986, pp. 97-102); Dickens and Leonard (1985); Farber (1987). 


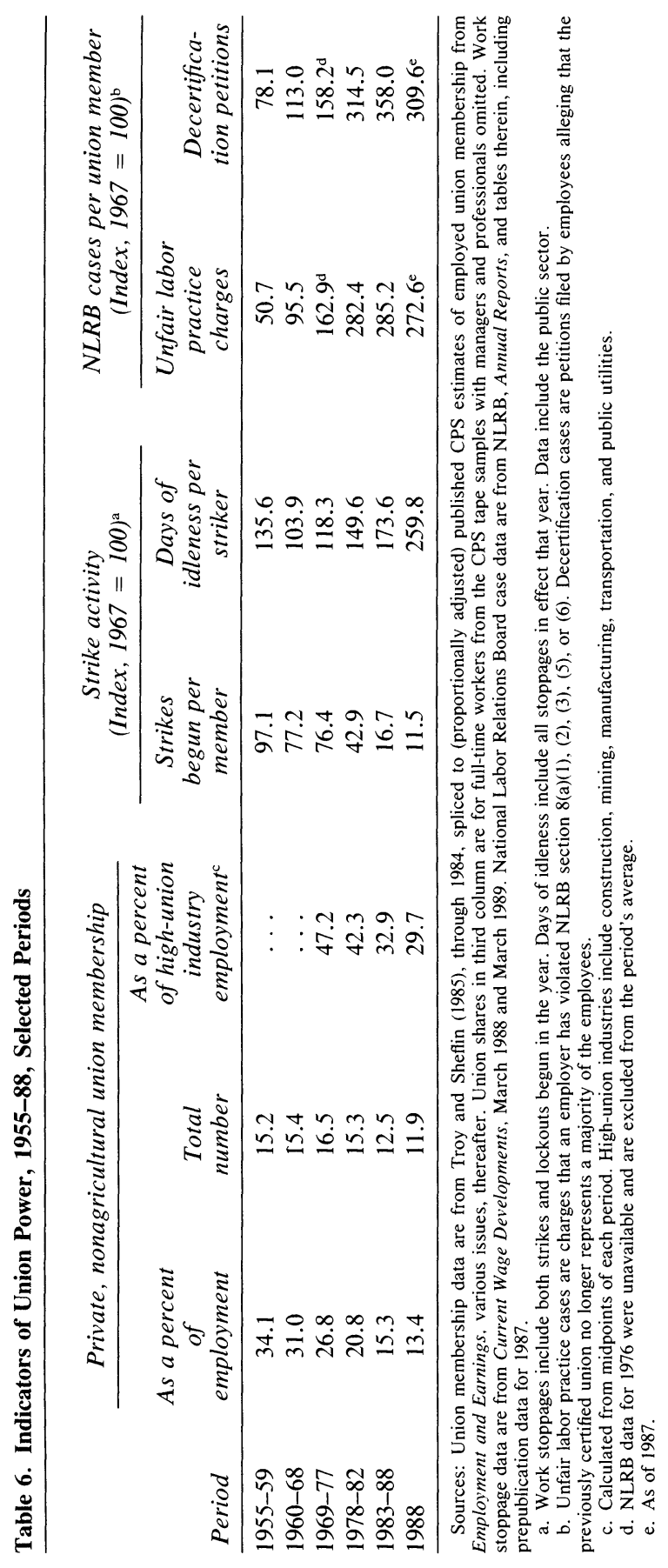


Almost surely the decline in total numbers is damaging to unions' dollar revenue, thus to their ability to lobby and to represent workers successfully in collective bargaining, including conducting successful strikes, paying for the direct costs of collective bargaining including court and legal costs, and paying salaries to union officers and employees. But union membership in the overall economy, although useful, is hardly a complete statistic. Unions have always been strong in certain sectors of the economy, such as in manufacturing, mining, construction, and transportation (and, more recently, government), while other sectors have been largely unorganized.

The third measure of union power, and by far the most important, is the percentage of union employment in traditional union strongholds (third column). Based on the CPS samples, we calculate that, as late as 1973-74 (the first two years the CPS figures are available), unions represented 47.2 percent of full-time nonexecutive, nonprofessional employment in construction, mining, durable manufacturing, and transportation and public utilities. ${ }^{19}$ In 1987, this figure had fallen to 31.2 percent. In construction, the decline was from 43 percent to 26 percent. In mining, the decline was from 56 percent to 27 percent, and in durables, from 50 percent to 32 percent. In transportation and public utilities, the decline was from 58 percent to 42 percent.

Consequently, in most of the traditionally heavily unionized U.S. industries, there is now at least a fringe, and often a substantial presence, of nonunion workers and firms. With international capacity included in traded goods, the union coverage of relevant capacity is obviously even smaller. ${ }^{20}$ Based on these latter percentages, unions appear to be critically weaker in 1989 than they were even a decade earlier, certainly much weaker than they were in 1969.

That union premiums remain stubbornly high even in the face of declining employment shares may seem puzzling. In other words, if unions have been weakened, how do they succeed in maintaining high premiums? One answer is that unions have fought hardest to maintain high premiums for their senior members, while firms have fought hardest to retain or increase their flexibility in shifting jobs out of the union

19. Although these figures can be faulted for being at too high a level of aggregation, two-digit industries show similar results.

20. On the effects of international competition, see Vroman and Abowd (1988). 
sector-for example, by subcontracting work to lower-cost nonunion firms, shifting work to nonunion subsidiaries of the same firm, directly using nonunion workers for certain tasks, or substituting capital for labor. Firms are more willing and able to accept higher wages for a union work force that is a declining percentage of their labor or overall input costs. A second answer is that in cases where such flexibility has not been possible, some firms have exited the union sector entirely. This issue is discussed later in the context of the strike and decertification election data. Wage reductions that occur after a firm becomes nonunion will obviously not lower the union premium. A third answer, and perhaps the most important, is that some of the adjustment has been in the form of a reduction in market share of unionized firms. ${ }^{21}$

\section{Strike Activity}

The amazing feature of the strike data in table 6 is that strikes have all but disappeared. Strikes were frequent throughout the 1969-77 period of increasing union premiums, averaging 76.4 per union member on an index with $1967=100$. They fell to 42.9 per union member during 197882 , as premiums leveled off. Strike activity then plummeted during the period of declining premiums and union employment shares after 1983. Since the strike series has membership as a deflator, the decline in strikes is particularly impressive. Many fewer union members are involved in many fewer strikes.

We believe that the answer to the puzzling decline in strike activity is found in the final three columns of table 6 . The point to be made is that the parties now litigate rather than strike over their differences. When

21. In earlier papers, we have noted the relationship between high premiums and low employment shares, and argued that the relationship went from exogenous premiums to endogenous employment shares. For example, in the increasing-premium industrial sector, union employment shares have declined sharply. Conversely, in sectors with small wage premiums, such as services and finance, unions have fared better, maintaining their employment share. In services, where the premium remained unchanged, the employment share has increased 3 percentage points. See Linneman and Wachter (1986); Linneman, Wachter, and Carter (1990). A similar argument has been advanced, in a series of important papers, by Hirsch and others. They have shown that high union premiums have resulted in significant profit declines in unionized firms and, perhaps more significantly for employment shares, in lower rates of investment in plant, equipment, and R\&D. See Hirsch and Connolly (1987); Addison and Hirsch (1989); Bronars and Deere (1990); and Ruback and Zimmerman (1984). 
strikes occur, they are now more frequently a fight to the finish, with the firm looking to union decertification rather than to a new contract to resolve the strike.

The fifth column, which shows days of idleness per involved worker, provides an indicator of the intensity of the strikes that do occur. Since the divisor is the number of members involved in strikes, the actual number of strikes does not affect the series. Instead, the series is high when the strikes are prolonged. Unlike the strike-per-member series, this figure is currently close to all-time highs. Although there are many fewer strikes now than in the past, once a strike begins, it is likely to last much longer than it would have in the past. Strike intensity has been high throughout the 1980s as the premium first leveled off and then declined. Conversely, in the early 1950s and late 1960s when the number of strikes was high, intensity was low.

\section{Unfair Labor Practices and Decertification Petitions}

The last two columns of table 6 present figures on the number of unfair labor practice allegations brought against employers and the number of union decertification elections requested, each an index per union member, with $1967=100$. Unfair labor practices are management or union actions that violate the National Labor Relations Act. Two of the most frequent unfair labor practice allegations involve section 8(a)(3), which prohibits management discrimination against union members, and section 8(a)(5), which requires management to bargain collectively with the union. The prototype 8(a)(3) case emerges during union certification and decertification elections, but can also occur during strikes, particularly when replacement workers are being hired. The prototype 8(a)(5) case involves a firm taking a unilateral action that the union believes to be a mandatory topic of bargaining.

The sharp upward trend in unfair labor practice allegations beginning in the late 1960s and early 1970s provides solid empirical support for the hypothesis that management opposition to unions has increased significantly since the late 1960s. Richard Freeman has fitted a wage premium to this unfair labor practice data and found a significant relationship between higher premiums and increased unfair labor practices. A second equation showed a further link from increased unfair labor practices to 
lower rates of new organizing. ${ }^{22}$ We have extended Freeman's regression analysis, which runs through 1980, through 1987, using our premiums and unfair labor practices series, and the relationships remain. That the wage premium peaks and begins to decline in the 1980s fits with the decline in unfair labor practices in the past few years.

Although it has been claimed by some that management opposition to unions toughened with the Reagan-appointed National Labor Relations Board, the evidence does not support the point. In the data above, the big uptick in unfair labor practices begins during the late 1970s, not the early 1980s. The timing of the increase is thus more consistent with the increasing premium than with changes in Washington. ${ }^{23}$ Similarly, by 1987 , allegations of unfair labor practices reverted to the level first reached in 1978 .

\section{Are the Legal Rules Changing?}

The strength of labor unions and their ability to negotiate wages above market-clearing levels are ultimately determined by the legal rules that govern the union representation and collective bargaining processes. The question we address is whether the Republican administrations of the 1980 s, especially through changes in the makeup of the National Labor Relations Board and Supreme Court, have changed the legal rules of the game. The alternative is that management practice has changed the way the rules are applied..$^{24}$

Two issues of particular importance in the 1980 s are the rules governing the ability of management to reallocate resources from the union sector and into the nonunion sector and those governing the rights of management in hiring replacement workers and decertifying unions. ${ }^{25}$ These issues have been actively litigated before the National Labor Relations Board, and, on appeal, before circuit courts and the Supreme Court.

22. Freeman (1986).

23. See Flanagan (1987, p. 100), who concludes that "the sustained growth of the unions' wage advantage during the $1970 \mathrm{~s}$. . . appears to have had a profound influence on the growth of unfair labor practice charges."

24. The analysis of this section is drawn from Wachter and Cohen (1988).

25. The ability to reallocate resources is at the heart of Lawrence and Lawrence (1985), which argues that unions played an end game during the late 1970s and early 1980s, effectively claiming the quasi-rents to capital. 
A clear example of a change in labor relations that springs from a change in management practice rather than a change in the legal rules is the increase in the hiring of replacement workers. Since 1938, the key case in this area has been Mackay Radio, which allows firms to hire replacement workers during a strike and to offer them permanent jobs. ${ }^{26}$ Until the late 1970s or 1980s, firms rarely made use of their rights under Mackay Radio to hire permanent replacements. Instead, firms used managers to replace striking workers temporarily. When replacement workers were hired, they were seldom offered permanent jobs.

When strikes occur today, replacement workers are more likely to be offered permanent jobs. Once management has adopted this strategy, resolution of the strike becomes not only more difficult, as union hostility increases, but also less important to management. The result is longer strikes. After a certain duration, and after a critical mass of replacement workers is hired, workers can petition for a new election to decertify the union.

Direct evidence proving that firms are increasingly using their 1938 rights under Mackay Radio is not available. Given that hiring replacements is often linked to decertification petitions, however, the decertification data in table 6 indirectly supports the claim, as does the dramatic increase in strike intensity. More broadly, the unfair labor practice data indicate increased management opposition to unions, with the significant increase during the late 1970s. With the legal rule unchanged since 1938, one must look for other explanations. An obvious one is the high union premiums that have been around only since the 1970 s. ${ }^{27}$

The rules governing plant closings and relocation are based on newer decisions. It is in this area that unionized firms may now have greater discretion than they once enjoyed or, more correctly, thought that they enjoyed. At issue is which topics are mandatory subjects of bargaining. For example, if the decision to relocate is not a mandatory topic,

26. NLRB v. Mackay Radio \& Telegraph Co., 304 U.S. 333 (1938).

27. Political influences, however, certainly do play a role. For example, it can be argued that the Reagan administration's firing of striking air traffic controllers was the "green light" to firms to hire replacements. Of course, the cases are not identical because the air traffic controllers' strike was illegal. Still, illegal strikes by municipal unions in the 1960 s were more frequently resolved by making the strikes legal, rather than by discharging the workers. 
management can unilaterally implement and the union cannot strike over the decision to relocate. ${ }^{28}$

In simple terms, the rules mean that management decisions to implement partial plant closing, work relocation, asset sales, and even some types of subcontracting are not mandatory topics. This is especially the case when there are circumstances that require quick action and involve a valid business justification. Cases would be decided differently if the decision was motivated by "anti-union animus." The key point for our purposes is that managerial decisions based on the high cost of a union contract satisfy the business justification rule. More generally, the law protects only the bargaining process and not bargaining outcomes, such as wage premiums. ${ }^{29}$

\section{Some Additional Conclusions}

From this review of employment shares and institutional variables we find no evidence that a change in union wage premium regimes is likely to occur. First, unions are continuing to experience employment losses, and union power, as measured by the percentage of workers unionized in relevant product markets, is much lower than in the late 1960s. Second, management in the 1980 s has a more confrontational approach to collective bargaining than it had in the 1960s, when the regime last changed to increasing premiums. Given the default settings of labor law, a determined management has considerable discretion to reduce the effects of high union premiums. One reason that union wages do not appear to be under greater pressure is that, in some cases, firms have either shifted work out of the union sector or become entirely nonunion.

28. First National Maintenance Corporation v. NLRB, 452 U.S. 666 (1981), is the Supreme Court's 1981 case involving plant closings. The NLRB followed this ruling in 1984 in deciding Otis Elevator Company, 269 NLRB 891 (1984), which governs relocations. These cases are more susceptible to the argument that the law has changed, since in deciding First National Maintenance, the Supreme Court primarily relied on the concurring rather than the majority opinion in Fibreboard Paper Products Corp. v. NLRB, 379 U.S. 203, 209 (1964).

29. Although the law does not explicitly address the premium issue, it is at least implied in the cases. For example, in Otis Elevator, a case in which a firm shifted work from a high-cost union plant to a low-cost nonunion plant, the parties themselves stipulated that the firm's decision did not involve anti-union animus. The court then ruled that the firm's decision was covered by a broad management perogative clause in the collective bargaining contract. See Wachter and Cohen (1988). 


\section{Wage Change Equations for the Union and Nonunion Sectors}

Our discussion of the union sector has developed data and documented, rather than explained, changes in union regimes. Unfortunately, the institutional changes discussed above are simply not rich enough to serve as explanatory variables. Hence, to predict the course of union wages and the wage premium, we must turn to equations that have been developed to explain time series of aggregate wage developments. The two that we use are those presented at Brookings Panel meetings by George Perry and Robert Gordon. Central to our use of these equations as forecasting devices is our view that a norm shift over the near term is unlikely.

The equation specification most in keeping with the spirit of this paper is the Perry norm model. A difference is that his norms describe discrete shifts in the rate of wage inflation while ours describe changes in the direction of the union premium. Although these two norms are conceptually different, we find reverses in the premium trend coincident with Perry's break points for his aggregate wage norm shifts. The union premium turns upward in 1970 just as Perry's norms signal, other things being equal, increasing wage inflation. Similarly, the premium turns downward in 1983just as Perry's norm shifts to decreasing wage inflation.

Perry intended his norm shifts to fit the aggregate data with the implication that they are as relevant to the union as to the nonunion sector. Of course, our union premium is also determined by the actions of the two sectors. Although our favored interpretation of events is one of exogenous behavioral shifts in the union sector, we do not preclude the existence of norm shifts in the nonunion sector.

The second model that we use is the Gordon model..$^{30}$ It differs from the Perry specification in that it subtracts the inter-NBER benchmark trend rate of productivity growth from the dependent variable. Gordon's equations also have a broader array of variables, each of which we tested in both union and nonunion equations.

Given our limited agenda, we have not embodied our equations in a more general model with price and unemployment equations-a limitation that we do not view as serious for our parameter estimates since

30. Gordon (1985 and 1988). 
there is little evidence of important simultaneous equations bias in singleequation wage models, even when those equations are for the aggregate economy. Obviously, the problems are more severe for our forecast period, which misses the feedback from wages to prices. Given the lags in the equations, this is primarily a limitation in the out years of our forecasts.

Our dependent union and nonunion variables are new and have not previously been used in wage equations. The major agreements series is available in one form or another back to 1959 and requires only a few adjustments to provide comparable numbers throughout that period. ${ }^{31}$ By beginning our sample period with 1959 we have a robust measure of union wages. Our ECI nonunion-nonexecutive series is available only back to 1975. Since we are most interested in current values, and the $\mathrm{ECI}$ is now 14 years old, it is inefficient to throw out the ECI information. Although it has pitfalls, our approach is to splice together the comparable ECI and HEI low-union series. (These two series are used in the fourth column of table 5.) $)^{32}$

The regression results appear in table 7. The Perry norm union and nonunion equations are equations 1 and 2 , respectively. The comparable Gordon equations are equations 3 and 4 . A hybrid of the two is in equations 5 and 6.33

Although the individual lagged wage and price terms vary across the equations, they all have sums that are insignificantly different from unity. The differences across the equations are not surprising since the joint confidence interval is an ellipsoid that allows the individual values to

31. Effective mean wage adjustments are available back to 1968. Before 1968, we use medians that are available back to 1959 . Quarterly data are only available after the third quarter of 1973. Before that date, we estimate within-year quarterly variations from a loglinear projection onto seasonal dummies (restricted to a zero sum) and quarterly variation in the HEI union series. With a starting date of 1959 , we need the HEI union series only for initial lagged values.

32. The HEI and ECI are not very different from each other during the mid-1970s when the ECI is first available, and so we have no preconceptions as to whether the ECI series, if available back to the 1950s, would have diverged from the HEI. As a first approximation, we simply splice the HEI series to their comparable ECI or major agreements series.

33. Unlike Gordon's dependent variable, which includes an adjustment for nonwage benefits, we use straight wages, because we lack nonwage benefits broken into union and nonunion sectors. Similarly, we do not attempt to measure productivity across union and nonunion sectors. Hence, his productivity trend is subtracted from the dependent variable in equations 3 and 4 of table 7. 
vary greatly while keeping the sum close to their given level. As expected, the sum of the lags is smallest in the Perry equation, where the norm dummies reduce their impact.

The unemployment term is also generally significant, with the largest impact in the nonunion equations. That result is expected, given the assumption that union wage setting is less attuned to excess demand conditions than is nonunion wage setting.

We used all of Gordon's variables in unreported equations, but of the additional variables only the CPI-relative (CPI-GNP deflator) was statistically significant in most equations. Hence, the other terms were omitted from all of the specifications. ${ }^{34}$ The CPI-relative term could not be used jointly with the Perry norm shift variables so we omitted the CPI-relative variable from the reported Perry equations.

In terms of the norm variables, the union equation has significant norm shifts in both 1970 and 1983 . The presence of norm shifts is tested by a norm coefficient significantly different from the preceding norm variable. For example, in equation 1 of table 7, with an initial norm intercept of 3.43, the first norm shift in 1970 causes union wages to accelerate, other things being equal, by 2.46 percentage points. After 1983 , union wages decelerate by 3.60 percentage points. These shifts are truly enormous.

The nonunion equation exhibits more moderate norm shifts. In equation 2, the nonunion acceleration in the 1970s is an insignificant 0.53 percentage point. The deceleration after 1983 is a high 2.54 percentage points, but even this is 1.1 percentage points less than in the union sector.

These equations suggest that the changes in the premium are driven more by the union sector than by the nonunion sector. Most important, they indicate that the enormous run-up in the premium in the 1970s was driven by an acceleration in union wages. The deceleration of wages in the 1980s is, however, a joint event.

The story behind the norm shifts fits our reading of the institutional literature as well as our earlier work. We view the post-1970 premium increase, particularly after the oil crisis of 1973 , as being partly a consequence of contract stickiness in the union sector in the face of supply shocks. The parties viewed COLA-type clauses as assigning the

34. These include the productivity deviation, relative import and food-fuel prices, and effective payroll taxes. 







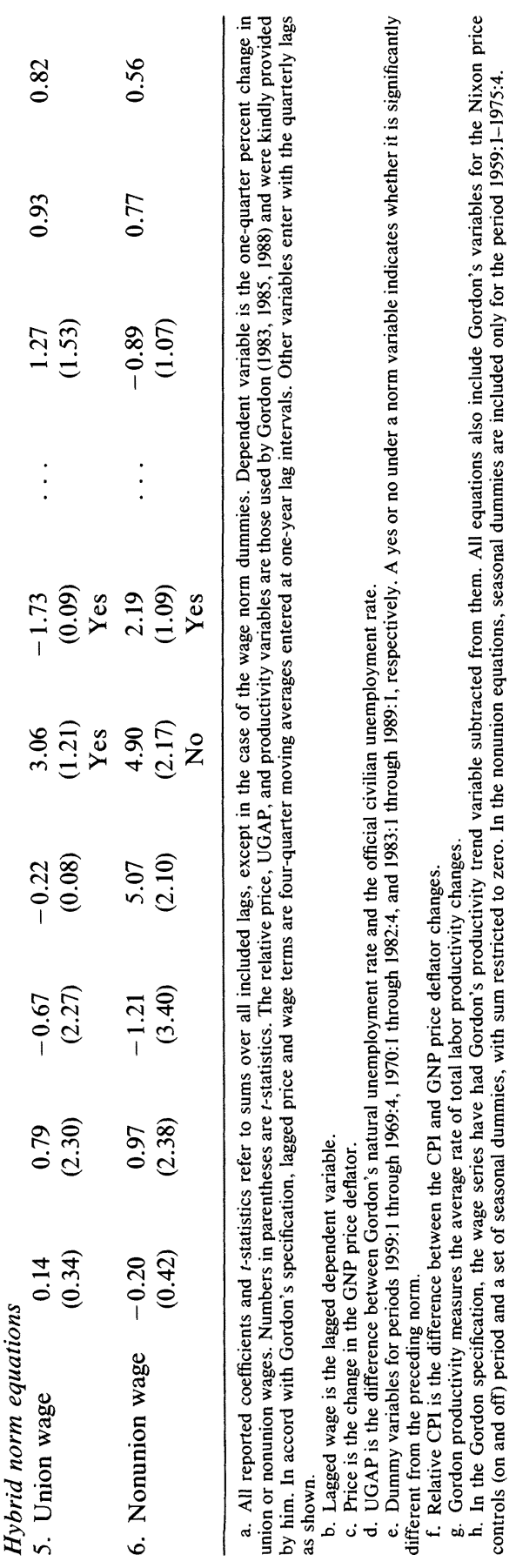


risk of inflation to the firm. The parties would not simply rewrite those terms when the inflation occurred, even when it was an atypical inflation in which CPI increases outdistanced GNP deflator increases. ${ }^{35}$ (Hence the correlation between the norm shift terms and the CPI-relative mentioned above.) This explanation also fits the fact that the premium in construction increased only in the early 1970s and decreased thereafter. Because construction contracts tend to be relatively short-term, they have fewer COLA clauses.

In this framework, the premium run-up between 1969 and 1972 can be viewed as a purposeful recapturing of the premium lost during the 1960s. But the events thereafter were partially an accident of the unique economic events. This can hardly be the entire story, but the evidence of the institutional variables is not rich enough to allow for statistical tests.

After 1983, with concession bargaining, the parties rewrote the contracts, including suspending COLA clauses and substituting bonuses for base rate increases. Based solely on actions taken in the unionized sector, a large decline in the premium might have been expected. Thus, the union norm shift in equation 1 should have closed the premium 3.6 percentage points per year. (This is of course an estimate rather than a result from a dynamic simulation.) However, as shown in table 5, the peak premium of 40.7 actually decreased at an average rate of only 1.3 percentage points per year from 1982 to 1988 . This smaller closing is the result of the nonunion norm shift. (Equations 1 and 2 predict a premium decline, due solely to the norm variables, of 1.1 percentage points per year.) In other words, the collective bargaining parties would have expected their actions to gain greater relative cost savings than they actually did. For the union sector to close the premium given the response of the nonunion sector would have forced a major reduction in nominal wages.

One of the interesting features of Gordon's equation is that he deducts a long-run productivity growth rate term from his dependent variable. In equations 5 and 6 , we included Gordon's productivity term as an independent value. Since the long-run rate is a fixed number over a cycle, each discrete change acts like a Perry norm shift. Hence, in these hybrid equations norm shifts become the change in either the Perry norm

35. Wachter (1986). 
Table 8. Wage Forecasts, 1989-92a

Percent

\begin{tabular}{lccc}
\hline Year & Union & Nonunion & Change in premium \\
\hline Perry specification & & & \\
1989 & 3.92 & 4.37 & -0.45 \\
1990 & 4.46 & 4.69 & -0.23 \\
1991 & 4.71 & 5.06 & -0.35 \\
1992 & 4.69 & 4.95 & -0.26 \\
Sum of change & & & -1.29 \\
$\quad$ in premium & $\ldots$ & $\ldots$ & \\
Gordon specification & & & -1.13 \\
1989 & 3.61 & 4.74 & -1.33 \\
1990 & 3.95 & 5.28 & -0.63 \\
1991 & 4.91 & 5.54 & 0.03 \\
1992 & 5.52 & 5.49 & -3.06 \\
Sum of change & & & \\
in premium & $\ldots$ & $\ldots$. & -1.07 \\
Hybrid norm specification & & & -1.28 \\
1989 & 3.71 & 4.78 & -0.58 \\
1990 & 4.01 & 5.29 & 0.13 \\
1991 & 4.99 & 5.57 & -2.80 \\
1992 & 5.60 & 5.47 & \\
Sum of change & & $\ldots$ & \\
in premium & $\ldots$ & & \\
\hline
\end{tabular}

a. The forecasts of independent variables are those of Data Resources, Inc., as of March 1989. Specific values are the following annual averages for 1989-92, respectively. Unemployment: 5.4, 5.5, 5.5, 5.5; fixed-weight GNP deflator: $4.4,4.8,4.6,4.5$; consumer price index: $4.8,4.6,4.9,4.9$.

variables or changes in the impact of the productivity variable. As a consequence, norm variables have to be considered jointly with the productivity variables. What we find is surprisingly little effect; the impact of the productivity term is to allow for a somewhat faster rate of nonunion wage growth and a slower rate of union growth beginning in the late $1970 \mathrm{~s} .{ }^{36}$

Table 8 shows the forecasts (as annual averages) from the equations of table 7. (The year 1989 consists of one quarter of actuals and three quarters of projections.) The forecasts show an acceleration, albeit a modest one, in wage inflation. In the union equation, the Perry specification forecast for 1989-92 and the Gordon specification forecast for

36. In an earlier draft we also included equations for our HEI union and nonunion equations. These equations were generally similar to their major agreements and spliced ECI nonunion-nonexecutive counterparts. 
1989-91 are compatible with the earlier warning signals from the current settlement data discussed above. As expected from the impact of the norm variables and the lower sum of lagged wage and price effects, the forecasts are generally lower in the Perry-type equations.

All of the forecast results are consistent with a continuing decline in the union wage premium. The 1988 narrowing of 2 percentage points is historically atypical and hence the fact that all equations predict a smaller rate of closing is expected. Based on our reading of the data on contract settlements, we believe the premium forecast from a hybrid-norm specification provides the best forecast, but the differences among them are small. Using the forecasts of the hybrid models, we project that the premium will close 2.9 percentage points through 1991. (We place no reliance on the projection of an increase in the premium in 1992, the last year of the forecast.)

\section{Conclusion}

Unions are traditionally regarded as the inflation wild card. In this paper, we have documented that union premiums have undergone long periods of year-to-year increases followed by periods of year-to-year decreases. Prolonged upswings throughout the 1950s and from 1969 to 1983 were followed by declines, first, from 1960 to 1969 and, most recently, from 1983 to 1989 .

These global shifts in the direction of the premium exactly date the Perry norm shifts in aggregate wage inflation equations. Thus, wage inflation was higher than expected during the 1970s and lower than expected throughout the 1960 s and from 1983 through the present. Using our union and nonunion wage series, we find that Perry norm shifts are more prominant in the union than in the nonunion sector. This is particularly true in 1970 when the union sector had a large, statistically significant norm uptick in wage growth, while nonunion wage growth continued along its historical path.

For today's labor market, the central historical event is the doubling of the union premium from 1970 to 1983 . According to one measure, the premium increased from 17.6 percent in 1969 to 35.6 percent in 1985. Although the premium has declined since 1985, the decline is small in comparison to the original increase. 
The size of today's union premium is central to our conclusion that inflation will not accelerate after 1989 the way it did after 1969. In 1969, after a decade of declining premiums, the premium was close to series lows. In 1989, even after several years of moderation, it remains close to series highs. This change in relative wages has combined with other developments to hamper the competitive position of unionized firms. In particular, both international trade and deregulation have disproportionately affected unionized industries.

The result of these developments is that the strength of labor unions has been seriously eroded. Union employment shares in the key industrial sectors have declined sharply since 1973 . There is an important nonunion presence in almost all of the traditional union strongholds. At the same time, management opposition to unions, as reflected in allegations of unfair labor practices and petitions for union decertification, have increased significantly since the 1960s. Unionized firms have also shown a great deal more aggressiveness in using those features of labor law that allow them to shift work out of the union sector or to hire permanent replacements for striking workers.

For the short term, our specific conclusion is that although the rate of compression in the union premium will slow, the current regime of union wage restraint will continue. In terms of absolute rates of wage change, current settlements are showing an acceleration in union wages, but the acceleration is slight and union wage growth should remain approximately 0.5 to 1.0 percentage point below nonunion wages. With inflation at approximately 4.75 percent and unemployment at 5.5 percent, continued modest acceleration to 4 percent (union sector) or 5 percent (nonunion sector) is the prediction of equations with constant norms.

Current high levels of capacity utilization have temporarily weakened the pressure on the union sector. But, unless the premium shrinks much more than predicted above, unionized firms will remain the high-cost producers who lose market share over time. Hence, the long-run outlook for the union sector is bleaker than is the short-run outlook.

Although there is a tendency to "blame" unions for the increase in the premium and for the resulting difficulties, a good case can be made that neither unions nor management-for the inflationary contracts were voluntary agreements of two parties-is to blame. For commercial contracts involving long-term relationships, the supply shocks of the 1970 s brought considerable disarray. Such contracts were simply not 
designed to handle the acceleration in inflation after 1970, and the methods for adjusting to new economic conditions were rudimentary. Although it has taken years, most of these long-term commercial contracts have by now been reformed, often through lump-sum awards that also reset marginal costs to competitive levels. In the union sector, the high premiums suggest that union firms' marginal costs are still out of line. Hence the bleak long-term outlook. ${ }^{37}$

37. See Wachter (1986); Joskow (1976). A leading case is Aluminum Company of America v. Essex Group, 499 F.Supp. 53 (1980). In that case, an escalator clause did not work as intended, significantly understating the cost increase that occurred. 